\title{
Induction of Interleukin-8 Expression in Neuroblastoma Cells by Retinoic Acid: Implication of Leukocyte Chemotaxis and Activation
}

\author{
KUENDER D. YANG, SHIN-NAN CHENG, NIA-CHENG WU, AND MEN-FANG SHAIO \\ Department of Pediatrics, Tri-service General Hospital [K.D.Y., S.-N.C.J, and the Department of Parasitology \\ and Tropical Medicine [N.-C.W., M.-F.S.], National Defense Medical Center,
}

Taipei 107. Taiwan, Republic of China

\begin{abstract}
Neuroblastoma cells in response to retinoic acid (RA) exhibit differentiation. RA, which can promote tumor cell differentiation, has also been shown to regulate tumor-infiltrating leukocytes. In an attempt to explore the relationship between RA-induced neuroblastoma cell differentiation and leukocyte chemotaxis, we investigated expression of IL-1 $\beta$, IL-8, granulocyte-macrophage colony stimulating factor, and tumor necrosis factor- $\alpha$ in the undifferentiated and RA-induced differentiated neuroblastoma cells. Using SK-N-SH neuroblastoma cells, we found that RA induced differentiation of SK-N-SH cells as demonstrated by down-regulation of $\mathrm{N}$-myc gene expression, cell-cycle arrest in G1 phase, and phenotypic change. Neither RA-treated nor untreated neuroblastoma cells expressed IL-1 $\beta$, granulocyte-macrophage colony stimulating factor, or tumor necrosis factor- $\alpha$ mRNA. RA-treated but not untreated SK-N-SH cells expressed IL-8 mRNA in a time- and dose-dependent fashion. As determined by ELISA, IL-8 levels were detectable in the culture supernatants from RA-treated, but not untreated, neuroblastoma cells $(2.65 \pm 0.43$ versus $0.05 \pm 0.04 \mathrm{ng} / \mathrm{mL})$. Using neutrophil and lymphocyte chemotactic assays, we found that RA-treated but not untreated culture supernatants of neuroblastoma cells promoted neutrophil and lymphocyte chemotaxis. The RA enhancement of neuroblastoma cellmediated leukocyte chemotaxis was significantly blocked by anti-IL-8 neutralizing antibodies. These results suggest that RA-induced neuroblastoma cell differentiation is associated with production of functional IL-8, which may be involved in the leukocyte infiltration and activation resulting in tumor regression. (Pediatr Res 34: 720-724, 1993)
\end{abstract}

\section{Abbreviations}

RA, retinoic acid

TNF $\alpha$, tumor necrosis factor- $\alpha$

GM-CSF, granulocyte-macrophage colony stimulating factor

cRA, 13-cis-RA

tRA, all-trans-RA

Received March 2, 1993; accepted July 8, 1993.

Correspondence and reprint requests: Kuender D. Yang, M.D., Department of Pediatrics, Tri-service General Hospital, Ting-Chow Road, Section 3, \#40, Taipei 107, Taiwan.

Supported in part by grants NSC 800412 -B016129 from the National Science Council and DOH 82-HR-C03 from the Department of Health. Taiwan, ROC.
Neuroblastoma originating from neural crest is the most common extracranial solid tumor of childhood. A recent report from Denmark showed that one in 7000 live births might develop neuroblastoma before age 15 y (1). Neuroblastomas in patients less than 1 y old tend to differentiate and regress spontaneously, and even in disseminated diseases with liver, skin, or bone marrow metastasis, designated as stage $4 \mathrm{~S}$, they may regress completely $(1,2)$. The mechanism of spontaneous differentiation and regression of the neuroblastomas remains to be determined. The evidence that neuroblastoma cells in vitro differentiate into more mature ganglion cells or neuroepithelial cells in response to differentiation agents such as RA (3) and nerve growth factor (4) indicates that some intrinsic factors may be directly or indirectly implicated in the differentiation resulting in regression.

$\mathrm{RA}$ derived from vitamin $\mathrm{A}$ or $\beta$-carotene is an important endogenous compound that regulates embryogenesis and vertebrate development $(5,6)$. Several clinical trials have been used to identify effects of RA on tumor differentiation therapy. cRA has shown effectiveness in the treatment of premalignancies such as oral leukoplakia lesion and laryngeal papillomatosis $(7,8)$. cRA, however, showed no significant effectiveness in the treatment of solid tumors or acute nonlymphocytic leukemia $(9,10)$. Recently, tRA has been shown to effectively induce complete remission of acute promyelocytic leukemia without showing disseminated intravascular coagulopathy $(11,12)$, a serious complication commonly seen in the acute promyelocytic leukemia induction therapy (13). Sidell et al. (3) and Pahlman et al. (14) showed that tRA could cause neuroblastoma cell differentiation to neuron-like or perineurium-like cells depending on different neuroblastoma cell lines tested. These results suggest that tRA may be involved in the spontaneous differentiation and regression of neuroblastoma cells

Patients with a lower grade of neuroblastoma tend to have a better prognosis $(1,15)$. Evidence has also shown that more differentiated neuroblastomas were more frequently associated with leukocyte infiltration (16). These data suggest that the prognosis of patients with a neuroblastoma may depend not only on differentiation of tumor cells, but also possibly on differentiation-associated leukocyte infiltration. RA, which can enhance neuroblastoma cell differentiation $(3,4)$, has shown effectiveness in regulating tumor-infiltrating leukocytes (17) and modulating leukocyte functions (18). In an attempt to clarify whether induction of neuroblastoma cell differentiation by RA was associated with expression of leukocyte-activating or chemotactic factors, we investigated IL- $1 \beta$, TNF $\alpha$, GM-CSF, and IL-8 gene expression in RA-induced differentiating neuroblastoma cells. We found that RA promoted neuroblastoma cell differentiation and induced functional IL-8 production capable of attracting neutrophils and lymphocytes. 


\section{MATERIALS AND METHODS}

Culture and differentiation of neuroblastoma cells. Human neuroblastoma cells, SK-N-SH (American Type Culture Collection, Rockville, MD), were regularly cultured in Eagle's minimal essential medium (Gibco Co., Grand Island, NY) supplemented with $10 \%$ FCS, $1 \mathrm{mM}$ glutamine, $0.1 \mathrm{mM}$ nonessential amino acids, $1 \mathrm{mM}$ sodium pyruvate, gentamicin $(50 \mu \mathrm{g} / \mathrm{mL})$, and penicillin $(100 \mu \mathrm{g} / \mathrm{mL})$ at a density of $1 \times 10^{5}$ cells $/ \mathrm{mL}$ in a $5 \%$ $\mathrm{CO}_{2}$-humidified incubator at $37^{\circ} \mathrm{C}$ and harvested using $0.02 \%$ EDTA in PBS. Differentiation of neuroblastoma cells induced by tRA (Sigma Co., St. Louis, MO) was determined by the change of morphology from tear-drop-shaped neuroblasts to epitheloid perineurium-like cells, decrease of tumor cell proliferation, cell-cycle arrest in Go/Gl phase, and down-regulation of $\mathrm{N}-m y c$ gene expression.

Assessment of tumor cell proliferation and cell-cycle proportion. Assessment of tumor cell proliferation was performed by a ${ }^{3} \mathrm{H}$ thymidine (ICN Radiochemicals, Irvine, CA) incorporation assay (19). Neuroblastoma cells $\left(5 \times 10^{4}\right.$ cells $\left./ \mathrm{mL}, 200 \mu \mathrm{L}\right)$ were put in microtiter wells and treated with RA $(1 \mu \mathrm{M})$ or vehicle alone for $2 \mathrm{~d}$ before $1 \mu \mathrm{Ci}$ of ${ }^{3} \mathrm{H}$-thymidine was added to each well. After an additional $5 \mathrm{~h}$ of incubation, cells were harvested and counted by a $\beta$-counter. Analysis of cell-cycle proportion in differentiated and undifferentiated cells was determined by a flow cytometric analysis of DNA content indicated by propidium iodide staining.

Detection of cytokine mRNA expression. Total cellular RNA from neuroblastoma cells was purified by the guanidine isothiocyanate-cesium chloride method (20). Total RNA was subjected to electrophoresis in $1 \%$ agarose-formaldehyde gels, transferred to nitrocellulose filters, and hybridized to one of the following ${ }^{32}$ P-labeled cDNA probes: the 5.4-kb HindIII insert of human GM-CSF cDNA, the 1.0-kb BamHI/EcoRI insert of N-myc cDNA (American Type Culture Collection), the 0.6-kb BamHI/ $S m a I$ insert of human IL-1 $\beta$ cDNA, the $1.1-\mathrm{kb} P s t \mathrm{I}$ insert of human TNF $\alpha$ cDNA, the 0.6-kb EcoRI insert of human IL-8 cDNA, and the $2.0-\mathrm{kb}$ Pst I insert of chicken $\beta$-actin gene (19). Hybridizations were carried out at $42^{\circ} \mathrm{C}$ for $16 \mathrm{~h}$ in $50 \%$ (vol/ vol) formamide, $2 \times \mathrm{SSC}(1 \times \mathrm{SSC}=0.15 \mathrm{M}$ sodium chloride and $0.015 \mathrm{M}$ sodium citrate), $1 \times$ Denhardt's solution, $0.1 \%$ SDS, and $200 \mu \mathrm{g} / \mathrm{mL}$ salmon sperm DNA (20). Filters were washed in $2 \times$ SSC- $0.1 \%$ SDS and $0.1 \times$ SSC-0.1\% SDS twice before being exposed to Kodak X-OMAT x-ray film. Results of mRNA expression were quantified by a densitometer (X-Ograph Ltd., Malmesbury, England).

Detection of $I L-8$. IL-8 levels were measured by ELISA. ELISA kits for IL-8 determination were purchased from Quantikine ( $\mathbf{R}$ \& D Systems Inc., Minneapolis, MN). Values were based on interpolation from a standard curve generated by samples of known concentration provided with each ELISA kit (19).

Neutrophil and lymphocyte chemotaxis. Neutrophils and lymphocytes were prepared as previously described (21). Studies of leukocyte chemotaxis were performed in the multiwell modified Boyden chambers (21). Lower chambers were filled with $25 \mu \mathrm{L}$ of culture supernatants from tRA-treated and untreated neuroblastoma cells or with recombinant IL-8 $(0.1$ to $10 \mathrm{ng} / \mathrm{mL}$; Genzyme Corp., Cambridge, MA) in the presence or absence of anti-IL-8 neutralizing antibody, which has an ability to neutralize 2-10 ng/mL human IL-8 at a 1:10000 dilution (Upstate Biotechnology, Lake Placid, NY). Upper chambers were filled with $50 \mu \mathrm{L}$ of neutrophils or lymphocytes $\left(2 \times 10^{6}\right.$ cells $\left./ \mathrm{mL}\right)$. Nitrocellulose membranes that have a relatively small pore size $(5 \mu \mathrm{m})$ and are thick (Millipore Corp., Bedford, MA) were layered between upper and lower chambers for neutrophil chemotaxis. Polycarbonate membranes that have a relatively large pore size $(8 \mu \mathrm{m})$ and are thin (Nucleopore Co., Pleasanton, CA) were used for lymphocyte chemotaxis. Reactions were carried out in a humidified incubator at $37^{\circ} \mathrm{C}$ for $120 \mathrm{~min}$. After incubation, filters were fixed in methanol and stained with hematoxylin.
Neutrophils or lymphocytes migrating completely through the filter were viewed in a $400 \times$ microscope field. Leukocytes in five random fields were counted. Each experiment included triplicate samples and was reproduced three times.

\section{RESULTS}

Induction of neuroblastoma cell differentiation by $t R A$. Neuroblastoma (SK-N-SH) cells in response to tRA $(1.0 \mu \mathrm{M})$ exhibited differentiation, showing phenotypic change from teardropshaped to epitheloid perineurium-like cells. The phenotypic change induced by tRA was observed within $3 \mathrm{~d}$, but was markedly different in $5 \mathrm{~d}$ as demonstrated in Figure 1. tRA at $1.0 \mu \mathrm{M}$ significantly down-regulated $(61 \%$ decrease $) \mathrm{N}-m y c$ gene expression in the neuroblastoma cells by $2 \mathrm{~d}$ (Fig. $2 A$ ). In addition, tRA $(1.0 \mu \mathrm{M})$ markedly suppressed neuroblastoma cell proliferation as determined by a ${ }^{3} \mathrm{H}$-thymidine incorporation assay (Fig. 2B). Using flow cytometric analysis of cell-cycle proportion of neuroblastoma cells, we found that tRA induced cell-cycle arrest, with $91.2 \%$ of RA-treated cells in the Go/G1 phase compared with $75.7 \%$ of the untreated cells (Fig. $2 B$ ). These results indicated that $t R A$ could effectively induce differentiation of SK-N-SH neuroblastoma cells.

Induction of $I L-1 \beta, I L-8, G M-C S F$, and TNF $\alpha$ MRNA by $t R A$. SK-N-SH cells did not constitutionally express IL- $1 \beta$, IL-8, GMCSF, or TNF $\alpha$ mRNA. IL- $1 \beta$, GM-CSF, and TNF $\alpha$ mRNA were also not detectable in the SK-N-SH cells exposed to tRA $(1.0$ $\mu \mathrm{M}$ ) for $1,2,3$, and $5 \mathrm{~d}$, whereas IL-8 mRNA was expressed by the RA-treated SK-N-SH cells in $1 \mathrm{~d}$. The induction of IL-8 mRNA expression by tRA $(1.0 \mu \mathrm{M})$ was time dependent, being minimally detectable at $6 \mathrm{~h}$ of incubation, maximally detectable at $24 \mathrm{~h}$, and down-regulated after $72 \mathrm{~h}$ (Fig. $3 A$ ). Coculture of SK-H-SH cells with vehicle $(0.02 \%$ ethanol) did not express IL8 mRNA during this culture period. As demonstrated in Figure $3 B$, expression of IL-8 mRNA in neuroblastoma cells treated with tRA for $24 \mathrm{~h}$ was concentration dependent, having a maximal IL-8 mRNA induction with the TRA concentration at 1.0 $\mu \mathrm{M}$. A lower tRA concentration (less than $0.1 \mu \mathrm{M}$ ) or a higher tRA concentration $(5.0 \mu \mathrm{M})$ induced much less IL-8 mRNA expression in the neuroblastoma cells than the $1.0 \mu \mathrm{M}$ concentration (Fig. $3 B$ ). When given serial dilutions of the total RNA obtained from the neuroblastoma cells treated by $1.0 \mu \mathrm{M}$ tRA

(A)

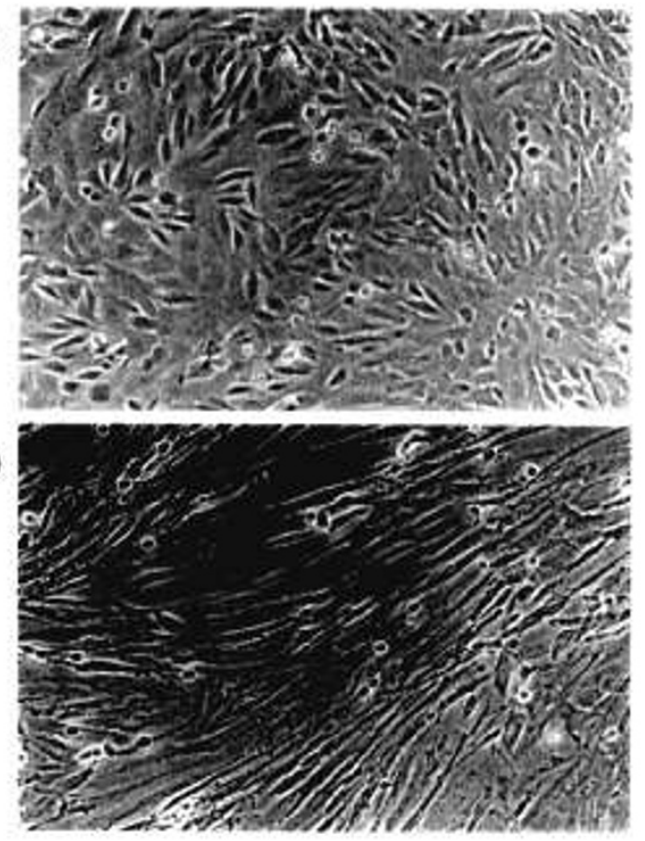

Fig. 1. Effect of RA on the phenotypic change of neuroblastoma cells. Cells were incubated with RA $(1 \mu \mathrm{M})(A)$, and vehicle $(0.02 \%$ ethanol) $(B)$ for $5 \mathrm{~d}$. 


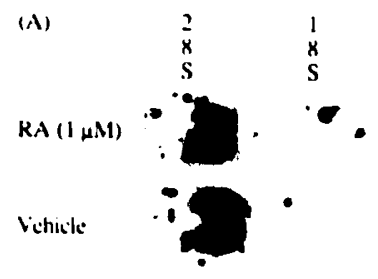

X.muc mRNA

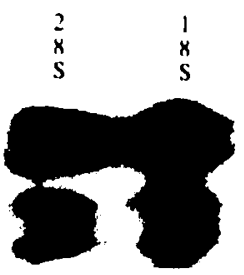

B.Actin mRNA
YANG $E T A L$.
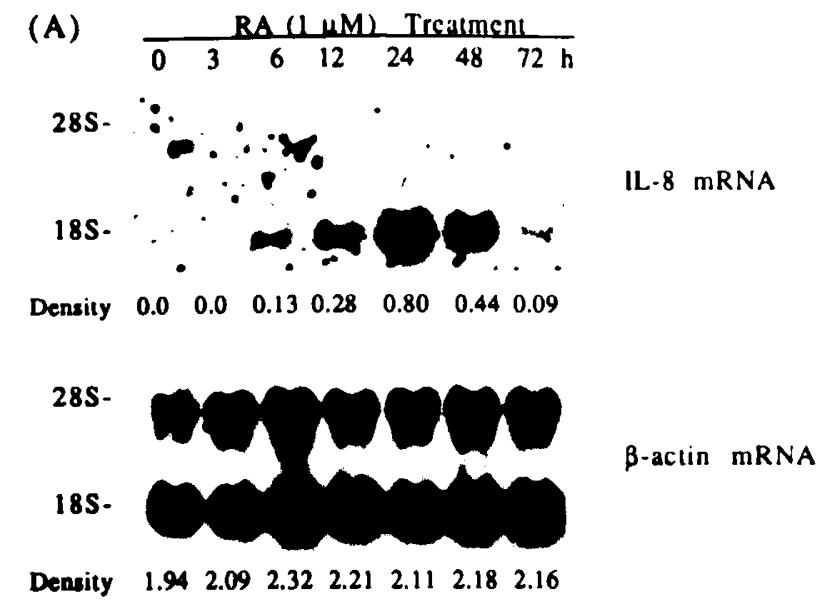

(B)

RA Treatment for $24 \mathrm{~h}$

Fig. 2. Effects of RA on the $\mathrm{N}-m y c$ gene expression, cell proliferation, and cell-cycle proportion of SK-N-SH neuroblastoma cells. Cells were treated with RA or vehicle for $2 \mathrm{~d}$. Total RNA $(25 \mu \mathrm{g})$ extracted from these cells was tested by $1 \%$ agarose gel electrophoresis and hybridized to ${ }^{32} \mathrm{P}$-labeled $\mathrm{N}-m y c$ and $\beta$-actin cDNA probes $(A)$. Density of $\mathrm{N}-m y c$ and $\beta$-actin mRNA expression was quantitated by a densitometer and shown as arbitrary units. Results of cell proliferation calculated from three triplicate experiments (mean $\mathrm{cpm} \pm \mathrm{SEM}$ ) were assessed by ${ }^{3} \mathrm{H}$ thymidine incorporation. Cell-cycle proportion data $(\%)$ were calculated from two duplicate experiments with flow cytometric analysis of propidium iodide staining $(B)$

for $24 \mathrm{~h}$, expression of IL-8 mRNA was detectable even in a very low concentration of total RNA $(2.0 \mu \mathrm{g} ; 1$ to 12.5 dilution) loaded for the study, and the density of IL-8 mRNA expression was proportionally correlated to the concentration of total RNA loaded (Fig. 4).

Production of IL-8 by neuroblastoma cells stimulated with tRA. To determine whether the expression of IL-8 mRNA by SK-H-SH cells was associated with secretion of IL-8, we used ELISA to detect IL-8 levels in the culture supernatants from tRA-treated and untreated SK-H-SH cells. Results (mean \pm SEM) calculated from three duplicate experiments showed that neuroblastoma cells cultured with tRA $(1.0 \mu \mathrm{M})$ for $3 \mathrm{~d}$ secreted high levels of IL-8 $(2.65 \pm 0.43 \mathrm{ng} / \mathrm{mL})$, whereas neuroblastoma cells cultured in vehicle $(0.02 \%$ ethanol $)$ alone did not produce a significant amount of IL-8 $(0.05 \pm 0.04 \mathrm{ng} / \mathrm{mL})$.

Differentiated neuroblastoma cell-mediated neutrophil and lymphocyte chemotaxis. IL-8 is well known to induce neutrophil and lymphocyte chemotaxis. Experiments were next performed to determine whether the IL-8-containing culture supernatants from RA-treated neuroblastoma cells caused neutrophil and lymphocyte chemotaxis. As shown in Figure 5, recombinant IL8 at $10 \mathrm{ng} / \mathrm{mL}$ effectively induced neutrophil chemotaxis. Culture supernatants from RA-treated neuroblastoma cells could significantly induce chemotaxis of neutrophils and lymphocytes, whereas supernatants from untreated neuroblastoma cells or culture medium containing $1 \mu \mathrm{M}$ RA had no effect on neutrophil and lymphocyte chemotaxis. An anti-IL-8 neutralizing antibody at a (vol/vol) concentration of 1:200, which could effectively block recombinant IL-8-induced neutrophil chemotaxis, significantly inhibited the RA enhancement of differentiated neuroblastoma cell-mediated neutrophil and lymphocyte chemotaxis (Fig. 5). These results suggest that RA-induced neuroblastoma cell differentiation is associated with functional IL-8 secretion.

\section{DISCUSSION}

Cytokines from the immune system can regulate functions of the CNS (22). Recently, evidence has also shown that neuronal

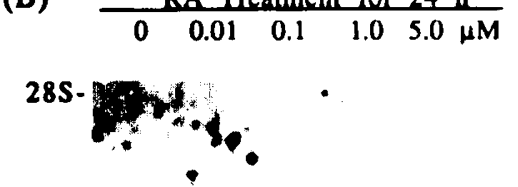

IL-8 mRNA

185-

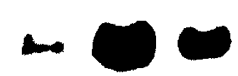

$\begin{array}{llllll}\text { Density } & 0.0 & 0.07 & 0.12 & 0.76 & 0.32\end{array}$

28S.

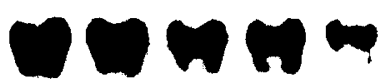

$18 S$ -

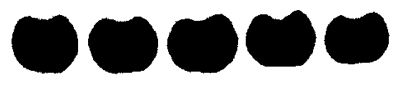

$\begin{array}{llllll}\text { Density } & 1.96 & 2.01 & 1.98 & 1.89 & 1.86\end{array}$

B-actin mRNA

Fig. 3. Effects of RA on IL-8 mRNA expression. RA induced IL-8 mRNA expression in a time-dependent fashion $(A)$ and in a dosedependent pattern $(B)$. Total RNA $(25 \mu \mathrm{g})$ was hybridized to ${ }^{32} \mathrm{P}$-labeled IL- 8 and $\beta$-actin cDNA probes. Results of mRNA expression were assessed by a densitometer and shown as arbitrary units.

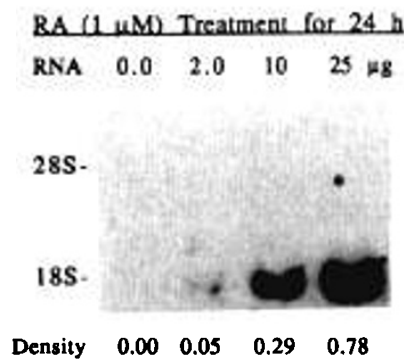

IL-8 mRNA

Fig. 4. Levels of IL-8 mRNA expression in serial dilutions of the total RNA extracted from neuroblastoma cells treated with tRA for $24 \mathrm{~h}$. IL8 mRNA expression levels were measured by a densitometer and shown as arbitrarily relative units.

and perineureal cells in the CNS can elaborate cytokines to affect immune functions $(23,24)$. Human astrocytes were also able to produce IL-1 $\beta(23)$, and glioblastoma cells could release many kinds of cytokines such as IL-1 $\beta$, IL-6, TNF $\alpha$, GM-CSF, and transforming growth factor $\beta$ (22-24). Furthermore, transforming growth factor- $\beta$ from glioblastomas has been proposed to have a potential link to Candida meningitis (25). The relationship between the peripheral nervous system and leukocytes remains to be determined. Using a neuroblastoma cell line, SK-N-SH, 
(A)

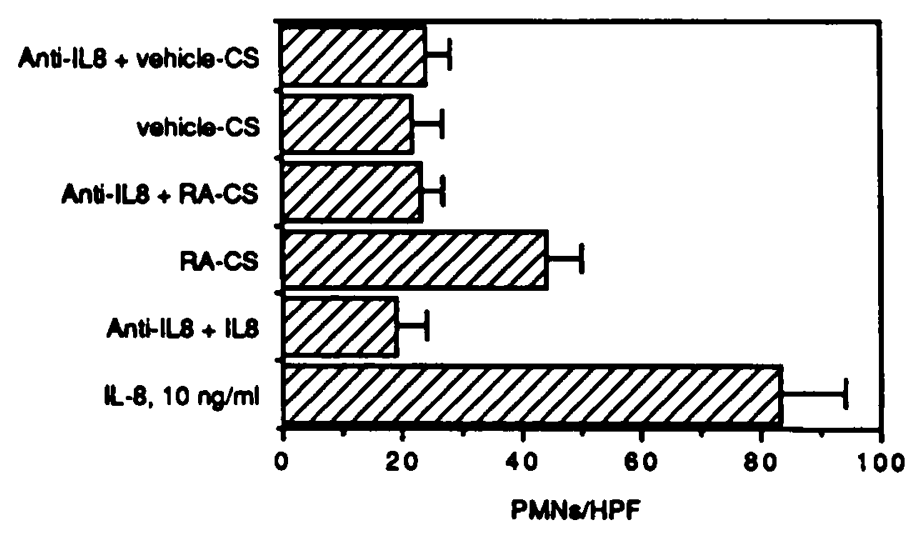

(B)

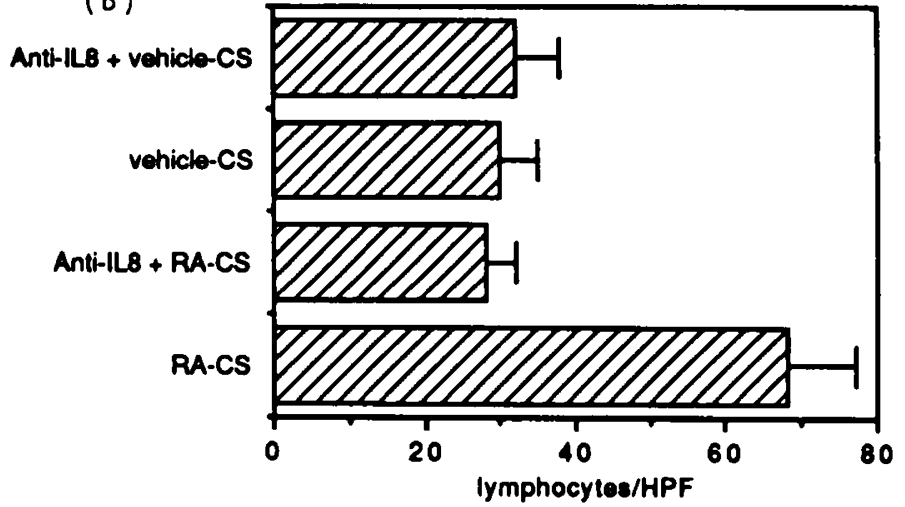

Fig. 5. Chemotaxis of neutrophils and lymphocytes induced by culture supernatants from differentiated and undifferentiated neuroblastoma cells. Culture supernatants from RA-treated $(1 \mu \mathrm{M})$ neuroblastoma cells $(R A-C S)$, but not culture supernatants from vehicle $(0.02 \%$ ethanol)-treated neuroblastoma cells (vehicle-CS), significantly induced neutrophil chemotaxis $(A)$ and lymphocyte chemotaxis $(B)$. An anti-IL-8 neutralizing antibody at a concentration of $1: 200(\mathrm{vol} / \mathrm{vol})$, which could neutralize IL-8 $(10 \mathrm{ng} / \mathrm{mL})$-induced neutrophil chemotaxis, effectively blocked RA-CS-enhanced neutrophil and lymphocyte chemotaxis. $P M N s$, polymorphonuclear neutrophils; $H P F$, high-power field.

we found that undifferentiated neuroblastoma cells did not express cytokines such as IL- $1 \beta$, TNF $\alpha$, GM-CSF, or IL-8, whereas RA-induced differentiated neuroblastoma cells released functional IL-8 that could effectively induce lymphocyte and neutrophil chemotaxis. The amino acid sequence of IL- 8 has a striking similarity with some transforming-related factors such as $9 \mathrm{E} 3$ and gro as well as cytokine-related proteins such as interferon- $\gamma$ inducible protein (IP $10 \gamma$ ) and platelet factor 4 (26). Whether IL-8 acts a growth factor, motility factor, or neural differentiation factor for neuroblastoma cells and their embryonic neural crest cells remains to be determined.

$\mathrm{RA}$, derived from vitamin $\mathrm{A}$ or $\beta$-carotene, has been shown in vitro to induce differentiation of neuroblastoma cells $(3,4)$ and to regulate tumor-infiltrating leukocytes in an animal model (17). Data from clinical and epidemiologic studies on neuroblastomas have indicated that young patients (less than $1 \mathrm{y}$ old) with a lower grade of tumor cells have a better outcome $(1,15)$. In addition, Martin and Beckwith (16) reported that the more differentiated the neuroblastoma, the more tumor-infiltrating lymphocytes were found in the histology examination. Based on these observations, we proposed that differentiation of neuroblastoma cells might be associated with induction of leukocyte chemotactic factor, which could induce leukocyte infiltration and activation, resulting in promotion of tumor regression. Recently, Birdsall et al. (27) have shown that induction of adhesion molecules on human neural cells is responsible for the cell surface interaction between neural cells and leukocytes. Data from the present study indicated that RA-treated, but not untreated, neuroblastoma cells expressed IL-8 mRNA and released functional IL-8 capable of attracting neutrophils and lymphocytes. Furthermore, we found that phorbol ester $(32 \mathrm{nM})$, a potent neuroblastoma cell differentiation inducer, could also induce prominent IL-8 expression in SK-N-SH neuroblastoma cells (data not shown). Taken together, these in vitro studies suggest that spontaneous regression of neuroblastomas may involve not only tumor cell differentiation, but also differentiation-associated immune responses. To test this hypothesis in vivo, additional studies with sequentially histologic and in situ IL-8 hybridization examinations of neuroblastoma specimens from patients under RA treatment are needed.

Randomized clinical trials of tRA treatment for neuroblastomas are ongoing (28). Some early phase trials using cRA showed partial effectiveness in reducing tumor content (28) or no significant effect in the treatment for advanced neuroblastomas when given as a single daily dose (29). The fact that RA given as a single agent could not induce terminal differentiation in all neuroblastomas in vivo was not unexpected, inasmuch as RAresistant neuroblastoma cell lines have been reported and most of the cultured neuroblastoma cells regain their growing ability after RA is removed from the medium (30). However, RA alone or in combination with other chemotherapeutic or antiproliferative agents may be beneficial in promoting terminal differentiation and preventing recurrence of neuroblastomas, presumably through its enhancement of cellular immunity, IL-2-induced lymphokine-activated killer cell function, and NK cell activity $(17,18,28)$ or its promotion of differentiation-associated leukocyte responses, as shown in the present study.

\section{REFERENCES}

1. Carlsen NLT 1992 Neuroblastoma: epidemiology and pattern of regression. Am J Pediatr Hematol Oncol 14:103-110

2. Brodeur GM. Seeger RC, Barrett A, Berthold F, Castleberry RP, D'Angio G, DeBernardi B, Evans AE. Favrot M. Freeman AI, Haase G. Hartmann O. Hayes FA, Helson L, Kemshead J, Lampert F. Ninane J, Ohkawa H, Philip T. Pinkerton CR, Prichard J, Sawada T. Siegel S, Smith EI, Yoshiaki T, Voute PA 1988 International criteria for diagnosis, staging, and response to treatment in patients with neuroblastoma. J Clin Oncol 6:1874-1881

3. Sidell N, Altman A, Haussler MR, Seeger RC 1984 Effects of retinoic acid (RA) on the growth and phenotypic expression of several human neuroblastoma cell lines. Exp Cell Res 148:21-30

4. Jensen LM 1987 Phenotypic differentiation of aphidicolin-selected human neuroblastoma cultures after long-term exposure to nerve growth factor. Dev Biol 120:56-64

5. Ruberte E, Kastner P, Dolle P, Krust A, Lerov P. Mendelsohn C, Zelent A, Chambon P 1991 Retinoic acid receptors in the embryo. Semin Dev Biol 2:153-159

6. Bryant SV, Gardiner DM 1992 Retinoic acid, local cell-cell interactions. and pattern formation in vertebrate limbs. Dev Biol 152:1-25

7. Hong WK. Endicott J, Itri LM, Doos W, Batsakis JG, Bell R. Fofonoff S, Byers R, Atkinson EN, Vaughan C 1986 13-cis-retinoic acid in the treatment of oral leukoplakia. N Engl J Med 315:1501-1505

8. Alberts D, Coulthard S, Meyskens F 1986 Regression of aggressive laryngeal papillomatosis with 13-cis-retinoic acid. J Biol Response Mod 5:124-128

9. Peck G, DiGiovanna J, Sarnoff D 1991 Treatment and prevention of basal cell carcinoma with oral isotretinoin. J Am Acad Dermatol 19:176-185

10. Bell B. Findley H, Krischer J 1991 Phase II study of 13-cis-retinoic acid in pediatric patients with acute nonlymphocytic leukemia. J Immunother 10:77-83

11. Huang ME, Ye YI, Chen SR, Chai JR, Lu JX, Zhoa L, Gu LJ, Wang ZY 1988 Use of all-trans-retinoic acid in the treatment of acute promyelocytic leukemia. Blood 72:567-572

12. Castaigne S, Chomienne C, Daniel MT. Berger R. Fenaux P. Degos L 1990 All-trans retinoic acid as a differentiating therapy for acute promyelocytic leukemias. I. Clinical results. Blood 76:1704-1709

13. Jones ME, Saleem A 1978 Acute promyelocytic leukemia: a review of literature. Am J Med 65:673-677

14. Pahlman S, Ruusala A, Abrahamssn L, Mattsson M, Esscher T 1984 Retinoic acid-induced differentiation of cultured human neuroblastoma cells: a comparison with phorbol ester-induced differentiation. Cell Differ 14:135-144

15. Makinen J 1972 Microscopic patterns as a guide to prognosis of neuroblastoma in childhood. Cancer 29:1637-1646

16. Martin RF. Beckwith JB 1968 Lymphoid infiltrates in neuroblastomas: their occurrence and prognostic significance. J Pediatr Surg 3:161-163

17. Eccles $S 1985$ Effects of retinoids on growth and dissemination of malignant tumors: immunological considerations. Biochem Pharmacol 34:1599-1610 
18. Douer D, Koeffler H 1982 Retinoic acid enhances colony-stimulating factorinduced clonal growth of normal human myeloid progenitor cell in vitro. Exp Cell Res 138:193-198

19. Yang KD, Stone RM, Lee CS, Chao TY, Cheng SN, Shaio MF 1992 Effect of picibanil (OK432) on neutrophil-mediated anti-tumor activity: implication of monocyte-derived neutrophil activating factors. Cancer Immunol Immunother 35:277-282

20. Stone RM, Imamura K, Datta R, Sherman ML, Kufe DW 1990 Inhibition of phorbol ester-induced monocytic differentiation and c-fms gene expression by dexamethasone: potential involvement of arachidonic acid metabolites. Blood 76:1225-1232

21. Yang KD, Liou WY, Lee CS, Chu ML, Shaio MF 1992 Effects of phenobarbital on the leukocyte activation: membrane potential, actin polymerization, chemotaxis, respiratory burst, cytokine production, and lymphocyte proliferation. J Leukoc Biol 52:151-156

22. Payne LC, Krueger JM 1992 Interactions of cytokines with the hypothalamuspituitary axis. J Immunother 12:171-173

23. Fontana A, Kristensen F, Dubs R, Gemsa D, Weber E 1982 Production of prostaglandin $E$ and interleukin-1 like factor by cultured astrocytes and $C 6$ glioma cells. J Immunol 129:2413-2419
24. Roszman T, Elliott L, Brooks W 1992 Modulation of T-cell function by gliomas. Immunol Today 12:370-374

25. Peterson PK, Chao CC, Hu S, Thielen K, Shaskan EG 1992 Glioblastoma, transforming growth factor- $\beta$, and candida meningitis: a potential link. Am J Med 92:262-264

26. Matsushima K, Morishita K, Yoshimura T, Lavu S, Kobayashi Y, Lew W, Appella E, Kung HK, Leonard EJ, Oppenheim JJ 1988 Molecular cloning of a human monocyte-derived neutrophil chemotactic factor (MDNCF) and of a human monocyte-derived neutrophil chemotactic factor (MDNCF) and the induction of MDNCF mR

27. Birdsall HH, Lane C, Ramser MN, Anderson DC 1992 Induction of VCAM1 and ICAM-1 on human neural cells and mechanisms of mononuclea leukocyte adherence. J Immunol 148:2717-2723

28. Smith MA, Parkinson DR, Cheson BD, Friedman MA 1992 Retinoids in cancer therapy. J Clin Oncol 10:839-864

29. Finflestein JZ Krailo MD, Lenarsky C, Ladisch S, Blair GK, Reynolds CP Sitar AL, Hammond GD 1992 13-cis-retinoic acid in the treatment of Sitarz AL, Hammond GD 1992 13-cis-retinoic acid in the treatment
children with metastatic neuroblastoma unresponsive to conventional children with metastatic neuroblastoma unresponsive to conventional
chemotherapy: report from the Childrens Cancer Study Group. Med Pediatr Oncol 20:307-311

30. Matsushima H, Bogenmann E 1992 Bi-modal differentiation pattern in a new human neuroblastoma cell line in vitro. Int J Cancer 51:250-258 